\title{
Author Correction: Supporting US public health experts
}

Ron Cohen (D), Cedric Francois, John Crowley, Paul Hastings, Rachel King, Ted W. Love, John Maraganore, Michelle McMurry-Heath, Jeremy Levin (10) and Cosignatories*

Correction to: Nature Biotechnology https://doi.org/10.1038/s41587-020-00767-6, published online 25 November 2020.

In the version of this article initially published, the name of cosignatory Tahir Mahmood was misspelled Tahi Mahmood. The error has been corrected in the PDF and HTML versions of the article.

${ }^{\star} \mathrm{A}$ list of authors and their affiliations appears online.

Published online: 17 December 2020

https://doi.org/10.1038/s41587-020-00792-5

(c) The Author(s), under exclusive licence to Springer Nature America, Inc. 2020

\section{Author Correction: Why the European Union needs a national GMO opt-in mechanism}

Dennis Eriksson, Eugénia de Andrade, Borut Bohanec, Sevasti Chatzopoulou, Roberto Defez, Nélida Leiva Eriksson, Piet van der Meer, Bernd van der Meulen, Anneli Ritala, László Sági, Joachim Schiemann, Tomasz Twardowski and Tomáš Vaněk

Correction to: Nature Biotechnology https://doi.org/10.1038/nbt.4051, published online 10 January 2018.

In the version of this article initially published, the surname of author Sevasti Chatzopoulou was misspelled Chatzopolou. The error has not been corrected in the original article.

Published online: 18 December 2020

https://doi.org/10.1038/s41587-020-00800-8

(c) The Author(s), under exclusive licence to Springer Nature America, Inc. 2020

\section{Publisher Correction: Glycosylase base editors enable C-to-A and C-to-G base changes}

Dongdong Zhao (D), Ju Li (D), Siwei LiD, Xiuqing Xin, Muzi Hu, Marcus A. Price, Susan J. Rosser, Changhao Bi $\mathbb{D}$ and Xueli Zhang (iD

Correction to: Nature Biotechnology https://doi.org/10.1038/s41587-020-0592-2, published online 20 July 2020.

In the version of this article initially published online, the editorial summary, "New base editors change $\mathrm{C}$ to $\mathrm{A}$ in bacteria and $\mathrm{C}$ to $\mathrm{G}$ in mammalian cells," was used as the title. The correct title is "Glycosylase base editors enable C-to-A and C-to-G base changes." The error has been corrected in the print, PDF and HTML versions of the article.

Published online: 29 July 2020

https://doi.org/10.1038/s41587-020-0648-3

(c) The Author(s), under exclusive licence to Springer Nature America, Inc. 2020 